\title{
Theoretic and Methodological Bases for the Organization of Ethnic Tours for Children
}

\author{
Svetlana N. Fedorova ${ }^{1}$, Elena V. Alekseeva ${ }^{1}$, Valentina V. Konstantinova ${ }^{1}$, Maria V. Lezhnina ${ }^{1} \&$ Zoya V. \\ Medvedeva ${ }^{1}$ \\ ${ }^{1}$ Mari State University, Yoshkar-Ola, Russia \\ Correspondence: Valentina V. Konstantinova, Institute of Pedagogics and Psychology, Mari State University, \\ Russia, Lenin Square 1, Yoshkar-Ola, 424000, Russia.
}

$\begin{array}{lcc}\text { Received: February 21, } 2015 & \text { Accepted: March 15, } 2015 & \text { Online Published: April 29, } 2015 \\ \text { doi:10.5539/res.v7n8p262 } & \text { URL: http://dx.doi.org/10.5539/res.v7n8p262 }\end{array}$

\begin{abstract}
Ethnic tourism is one of the trends of tourism with its own distinguished ethnical, language and cultural components. The purpose of this type of tourism is to get acquainted with the way of life, culture, traditions and customs of the people who live in harmony with the natural environment.

The Republic Mari El is a region where many nationalities and ethnic groups live in friendship and consent. But the nation, entitled to this territory, remains the Mari, who, regardless of the assimilation process, managed to preserve their own language, traditional folk clothes, their customs and traditions, their philosophy and religion, folk songs and dance.

When organizing an ethnic tour, the content of the tour and the form of the organization of the children's activity should be clearly defined. This also involves defining the level of the students' awareness of the aspects of history and culture, as well as biography and geography.

The acquired results of the survey helped to specify the content of ethnic tours for children in the Republic Mari El.

As a form of organization of ethnic tourism we suggest visit in our Republic's cities and districts, organizing game program sand trainings, as well as meetings with the famous folk craftsmen, participating in folk feasts, etc. The final form of ethnic tourism activity is a research and practice conference, where the students present their own research projects.
\end{abstract}

Keywords: ethnic tourism, ethnotouristic itineraries, the republic, districts, students, research projects

\section{Introduction}

Tourism is one of the ways of discovering the cultural heritage of a country. It includes tours, as well as travelling and exploring in order to combine recreation with informative and educational activity. At the present time, it is difficult to single out a unified classification of tourism. It can be generally characterized by the following features: the purpose of tourism, age groups, duration of a tour, and the travelling arrangement approach. The researchers have identified a social, ecological, cultural and educational tourism, as well as children's tourism and other types of tourism.

Children's tourism was introduced in the end of the $19^{\text {th }}$ century, and was especially popular in the beginning of the $20^{\text {th }}$ century, as tourism was getting more and more recognized by the domestic educational system. Later it developed into regional and his torical studies tourism, sports and health tourism, and served to pass onto the younger generations the accumulated historical experience and material and cultural heritage, as well as to form the values and value consciousness. Today children's tourism is used as one of the ways of the nation's cultural development and social adjustment of an individual.

The most widespread type of tourism is cultural and educational tourism, which helps to discover cultural values of a region and broaden ones horizons. Such educational touristic activity implies learning about various historical and archeological slights, visiting museums, and exploring historical itineraries. A more inform active way to gain some specific knowledge would be to attend lecture so seminars and trainings, as well as theatrical performances, festivals, religious celebrations, etc. To take back unforgettable memories, tourists may personally 
participate in folk festivals and expositions, in arts and crafts presentations or in culinary expositions of national cuisine.

One of the types of cultural and educational tourism, ethnic tourism stands out as a much promising trend of tourism development. Most researches define ethnic tourism as a means of discovering folklore, folk customs and handicrafts, the way of life and traditions of native population, their history and arts. Ethnic tourism allows to become familiar with the way of life of various ethnic groups and their national culture, and has become a relatively new but quickly developing trend of tourism. It fascinates an inquisitive explorer, allowing him to go back to the beginnings, the cradle of civilization, and experience its way of life and conditions, immerse into a unique world-view of different peoples by becoming familiar with their traditions, customs and their mentality.

The social functions of ethnic tourism include:

- Reinforcing tolerance towards various ethnic groups;

- Helping preserve cultural, social and ecological diversity, as well as landscape;

- Affirming national identity and helping to preserve a unique ethnic culture;

- Preserving diversity and multiformity of a modern world in contrast to modern trend of unification;

- Creating conditions for restoration of local cuisine and local crafts and ways of fabrication of traditional household items (Fedorova, 2014).

Ethnic tourism has drawn attention in the end of 1980s, as tourists headed to explore Latin America, Australia, North India, North Thailand, Egypt, etc. In Russia, it has become popular due to migrations and dispersal movements of local population, which began in the end of the $20^{\text {th }}$ century and continue today (Fedorova, 2014). The social and economic conditions in our country compelled the rural population, who has long lived in harmony with nature, to relocate and migrate to big cities and urbanized regions in the job search. As a result, the modern young generation is completely unaware or knows very little about the ethnic culture, customs and traditions of their parents. Most of modern young people live in big cities and don't consider themselves as a part of ethnic minorities. This dilemma can't be settled solely through educational implementations. Thus ethnic tourism can greatly contribute to getting accustomed to the ethnic cultural values and heritage, used as one of the methods of extracurricular recreational activity for children and youth.

In the Republic Mari El, ethnic tourism has long been subject to government's intent discussions, as well as has drawn close attention of education, cultural institutions and businesses. In 2012, at the XVI Session of Coordination Council of Culture by the Russian Ministry of Culture in Yoshkar-Ola the representatives discussed the subject of "Preservation of traditional folk culture as an ethnic tourism development approach". Similar ethnic touristic destinations which nowadays attract many tourists include some sights in the Republic of Karelia (Kizhi, Balaam, \& Petrozavodsk) and West Siberia territories (Novosibirsk, Kemerovo, \& Tomsk regions, the Altai Territory, the Republic of Altai), etc.

Still being as attractive as it is, ethnic tourism - and ethnic tourism for children as one of its streams - has not become a widespread practice in our country. Ethnic tours for adults are generally organized by businesses, and tours for children are set up by their enthusiastic teachers. Avery slow-paced development and lack of a large scope approach to ethnic tourism is explained by the following reasons:

1) The development to ethnic tourism requires considerable financial investments. The territory of Mari $\mathrm{El}$ is very attractive from the point of view of developing tourism and recreation activities. The increased funding invested in the region could attract more tourists to the region, thus creating additional jobs in the area of tourism and in related sectors. While arranging an ethnic tour we must consider such organizational aspects as accommodation in an ethnic settlement, daily meal so national cuisine, folk recreational activities such as social gatherings, entertainment, healthcare activities based on traditional medicine, transportation with ethnic means of transport, acquaintance with national arts and craft sand samples of folk handiwork, meetings with local intellectuals, visiting the national places of sightseeing, participating in decorative and applied arts classes to make their own handmade items, etc. All of this requires finances (Ivleva, 2014).

2) The concept of ethnic tourism as a frame of reference, and its role in the world, the environment and the society is not yet cultivated. The significance of this type of tourism is indeed in sufficiently studied at present. Meanwhile, ethnic tourism serves as a major factor for enhancing the educational and cultural development of population, and transferring and preserving ethnic values. Ethnic tourism also serves as an important healthcare factor (to support physical and mental wellbeing), and a means of developing such personal characteristic as 
ethnic tolerance and respectful attitude to the representatives of various nationalities and ethnic groups, which help to regulate inter-ethnic relations.

3) In many regions the infrastructure of ethnic tourism services is not developed. The ethnic sites provide a small range of facilities and ethno-communicational networks; districts and regions need be connected by the high-quality roads which will allow tourists a free access to the places of ethnic sightseeing, etc.

4) Ethnic tourism also involves qualified specialists, who are able to provide professional scientific, methodological, psychological and educational support, etc.

\section{Methods and Approaches}

Ethnic tourism support is a holistic systematic and organizational activity, which creates social, psychological and educational conditions for a successful development of each child. Scientific and methodological provisions for ethnic tourism are represented through a combination of a holistic systematic approach, competence-based, culturological, individual action approach, futurological and civilizational approaches.

Holistic systematic approach provides an objective analysis of complex systems from the perspective of various sciences; it determines the interconnection and interdependence of their components, and allows to represent the process of their formation through the models, which reflect the subordinate interrelation of their multiple elements.

Competence-based approach implies the ability to settle professional issues and solve typical professional problems based on knowledge, professional and life experience, values and tendencies (Huhlaeva, 2013).

Culturological approach acknowledges cultural background as a specific environment for existence and development of an individual, with education as its major component and the main channel to transfer knowledge and cultural experience, its symbols and meanings; it provides the formation of an individual, who bears and creates culture.

Individual action approach suggests that the main purpose, criteria and result of education is to develop an individual in a way that his actions would be determined not only by the external circumstances, but also by his "internal conditions". This approach requires the creation of educational concepts with consideration of peculiarities of those subject to it. It implies that in order to master the achievements of human culture every new generation must perform a similar (but not identical) activity, which previously led to those achievements (Leontiev).

Futurological approach considers the time frame characteristics of cultural existence (past, present, future), and provides a dynamic model of education, both in perspective and forecasting.

Civilizational approach regards the learning process in correspondence with the civilized requirements for the life in the world through observing universal values; the requirements for the life within an ethnic group through embracing national values; for the life in one's native land through respecting the values of their society; for the life in a professional environment through following their professional educational values; for the life in harmony with the spiritual world (Artamonova).

All these approaches can be applied as an integrated whole within the common methodological framework, as well as according to their logical sequence according to the corresponding scientific goals.

The goal for psychological and pedagogical support of the development of ethnic tourism is to provide each child with a corresponding psychological and pedagogical assistance and help them to successfully adjust to the ethnic environment, as well as to shape a system of ethnic ideas within the area of their immediate development. Ethnic tourism must consider the principles of selection of materials for regional studies, which are extensively covered in the works of local researchers (Safiullin, Stavrovskiy, \& Stroev). The materials for regional studies, which are used for children, should be of a regulated amount, and should correspond to the children's learning ability and their age, easy for perception and understanding. Never the less these materials should be scientific and provide a holistic and profound idea of the local culture in a way that would be interesting for children and correspond to their needs.

Ethnic tourism should avoid any sort of extremes-neither towards ethnocentristic tendencies, nor towards formalities. Thus, when being excessively focused on their own national culture, people risk to develop an ethnocentristic or even ethnofanatical identity in the children, which makes them focus their communication solely on their fellow countrymen. In case of formalistic approach to ethnic tourism the focus on external formalities and visible appearance of seeming activity may harmfully affect its content. Furthermore, it may affect all the aspects of educational process - the shaping of ethno touristic ideas in children, reaching of 
educational goals during ethnic tours, or even personal development of ethnic tourists.

A formalistic approach to shaping ethnic ideas in children simply implies a mechanical way of teaching about the local culture of an ethnic group without considering emotional involvement (i.e., when being taught about the customs and traditions of an ethnic group, their specific culture and valuable achievements, the children must be invited to respond with their feelings and soul). For malism reveals a thoughtless assimilation of information by the children, without perceiving and understanding it, without any interest to it. Meanwhile, emotions serve as a foundation for any kind of human activity, especially in realizing their goals and intentions, and represent a natural "fuel", which, if absent, makes all human initiative crush onto the first possible impediment (Anokhin). An ethnic tour specialist must remember and be aware of this.

When ethnic tours are approached with educational for malism, it leaves inferior all the efforts to develop ethnic awareness in the young tourists, who are entitled to preserve the moral and spiritual values of a certain culture and display respectful attitude to the moral and spiritual values of other cultures. A respectful tourist will not allow defiling the places and events that are sacred for a certain ethnic group, as well as will not tolerate mockery of his own cultural values.

A formalistic approach to the personality development of ethnic tourists is also displayed by the lack of new experience during tours (i.e., using same old itineraries, simply for a check) and the neglect to developing a certain behavioral style and attitude to those around.

\section{Results}

When organizing an ethnic tour, the content of the tour should be clearly defined. The program for ethnic tourism of children and youth in the Republic Mari El must provide reliable and detailed information about the regional and urban sights and places of interest, about the customs and traditions of the native population-Mari, about the way of life and the household peculiarities in the past and at present. Ethnic tours may be organized in their various forms: visiting the specific districts and cities of the Republic Mari El, setting up game programs and trainings, arranging meetings with the famous folk craftsmen, participating in folk events and feasts, etc.

Ethnic tourism provides a wide scope of opportunities to involve children in various activities, which help them to feel their own significance, experience connection with the profound history of their people, and learn their cultural traditions. Outdoor activities, moderate physical labor, recreational games, simple food prepared from natural products provide a very healthy experience for children - an experience which is neither possible, nor manageable in the urban environment, even when parents are fully supportive of the idea.

Traditional folk crafts are also very interesting and important for children. The idea that our ancestors used to hand make their own tableware, clothes and other household items, makes us think about their way of life. The boys may want to try weaving a stand birch bark, while the girls may enjoy the basics of embroidery and patchwork, and also try to work on a weaving loom. Any kind of hand craft helps to develop in emote or skills, as well respect the outcome of personal and other people's labor.

Fishing and hunting acquire a new, or rather initially old, meaning for children, i.e. become a means of existence and acquiring food, rather than entertainment. Modern children, who grow up in the environment of abundance where the food is "growing" in the supermarkets and can be accessed without any extra efforts, are often amazed at a full-course dinner prepared of several ordinary potatoes, a handful of flour and an egg. And one caught fish may serve to cook several dishes! The process of cooking tunes upon a state of peace and well being, which a housewife gives to her family and guests. To watch it, or to be lucky enough to participate in it, is a fortunate experience not only for children, but for adults too.

Feeding and taking care of domestic animals helps to develop a more stable psychic and teach about a particular designation of each living being. The barn and poultry-housed wellers are not just lovely creatures, which live there because their owners were so kind, but are those who also feed and labor, and make their own investment in the household. Taking care of animals even during several days helps a child develop a sense of responsibility.

A great way to understand and experience the authentic lifestyle is to participate in a large folk feast - the most impressive, complex and typical form of tradition. Seasonal feasts which celebrate the landmarks on the Wheel of the year were made by our ancestors not for entertainment, but rather to fulfill the people's need to be in the center of life, to feel its heartbeat and breath, to interact with past and future, and to gather common memories. To experience feasts and understand their profound meaning is very significant for children. In the city full of strangers the spirit of history is not as strong, and the feasts seem to be mere entertainment. In the villages, where all the feasts are by all means attended by the local elders, everything is performed as in the days of old - each voice is heard, the joyful dancing bears its particular meaning, all meals are symbolic. That is the kind of feasts 
to remember when a child! Ethnic tourism to remote settlements is a wonderful means of witnessing and experiencing all the colors of life, all joys and beauties of the world around us.

But before making an itinerary for an ethnic tour one must define the initial level of ethno touristic perception of children.

As the conducted survey (Fedorova, 2014) of primary school children indicated, only $20 \%$ of respondents could correctly answer all the questions about the flora and fauna of the Republic Mari El. The respondents appeared to have a poor knowledge of geography. They could not name the longest river, the biggest lake, the biggest district of the Republic Mari El. Only 5\% of the surveyed have correctly answered all the test questions. The children showed their good knowledge of literature. They were supposed to name the founder of Mari literature, a famous poet, and an actor of the first sound motion picture, etc. $92 \%$ of children have successfully answered these questions. Many wrong answers were given to name the author of the drama "Akpatyr". As for history questions, the respondents could not mention the district where the

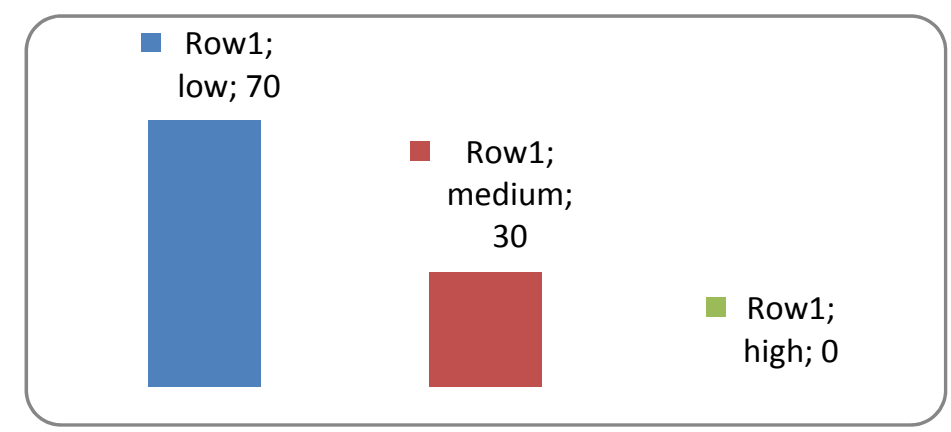

Figure 1. The level of ethnotouristic perception of the primary school children

The study of ethnotouristic perception of middle school children was similarly made in order to evaluate the level of awareness of their motherland (geography, biology, history, literature, art). The survey was made in the form of a multiple choice test with one correct answer to each question.

Answering the geography questions, $50 \%$ of children could not tell the total number of districts of our Republic, as well as the biggest and the smallest district by the occupied territory. Almost $90 \%$ of the surveyed could not name the date of publishing of the $1^{\text {st }} \mathrm{ABC}$-book in Mari language, and answer the question who is represented on the coat of arms of the Republic Mari El, and who was the first governor (voivode) of the Zar-city on Kokshaga-river. Also, the respondents had a difficulty in answering such questions as: there are ... rivers flowing on the territory of the Republic Mari El with a total length of more than $7000 \mathrm{~km}$; there are ... lakes in our Republic; etc. $70 \%$ of children could not name the founder of the $1^{\text {st }}$ Mari choir, who attained great success at the Russian choir competition, as well as the author of a painting called "The Cheremis wedding".

A visual chart of the level of ethnotouristic perception of the children of the $5-7^{\text {th }}$ grades is presented on the figure 2 . 


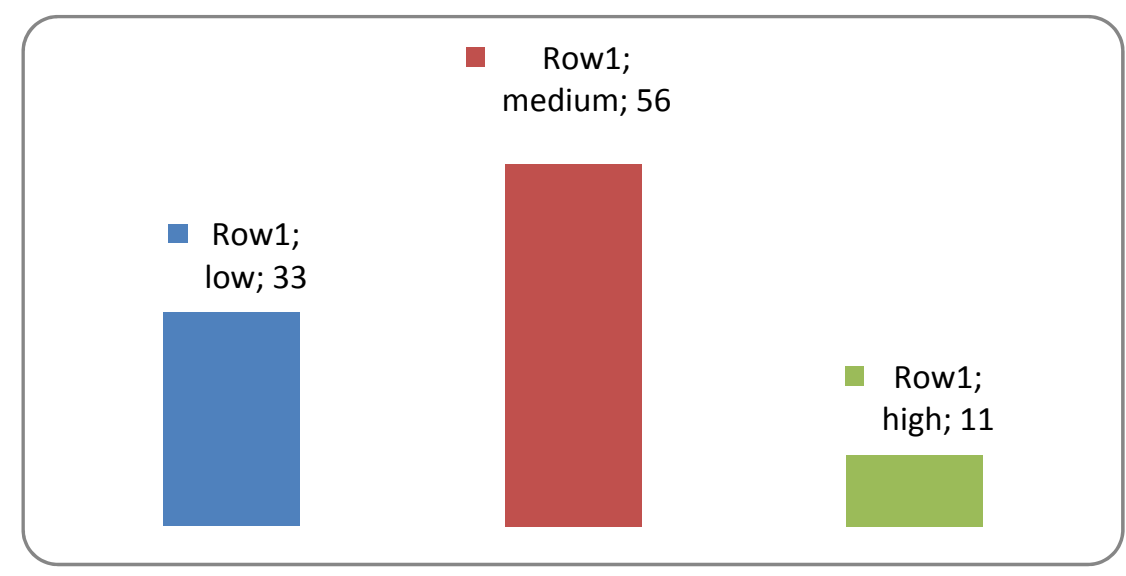

Figure 2.The level of ethnotouristic perception of the children of the $5-7^{\text {th }}$ grades

The results of the survey testify of the necessary corrective measures to take place in order to upgrade the level of ethnotouristic perception of the children by setting up the environment for ethnic tourism.

Ethnotouristic environment can be described as a territory rich in the objects of national culture and containing much information about the material and spiritual values of a certain ethnic group. The main purpose of creating an ethnotouristic environment is to make the cultural heritage of people available to all the interested groups of population. It may become even more accessible if provided as an informational resource.

As we have already mentioned, the preliminary results of the survey to determine the level of the children's awareness about the ethnic culture of the Mari people and the main places of ethnic interest of the Republic Mari El have shown a very low level of these perceptions. Thus in order to upgrade the ethnic awareness we have developed an electronic educational resource called "Ethno-journey in the Republic Mari El".

This electronic educational resource is designed for a wide targeted audience, as it can be partially used in preschool classes, and largely in schools for ethno-environmental and ethno-cultural studies, in vocational and higher educational establishments for students, and in teacher qualification courses. The informational capacity of the resource allows to apply various ethno-cultural educational technologies in the course of upbringing and education.

The electronic educational resource "Ethno-journey in the Republic Mari El" contains extensive information about the history and culture of the Mari people and the main attractions and places of interest of the Republic, and consists of 7 main sections:

- "Spiritual and material culture of the Mari people", which contains information about the religious views of the people, their attitude to the nature, about the Mari national heroes, prominent arts and culture figures, about the national arts and crafts, national clothes, etc.;

- "Natural environment and climate of the Republic Mari El" presents information about the geographic aspects, natural memorials and sights of our Republic, as well as a photo presentation called "Writers and artists of Mari El reflect on nature", which contains poems, riddles, quotes, photos of the paintings inspired by the Mari nature;

- "Ethnotouristic itineraries in the Republic Mari El" contains comprehensive information about the districts of the Republic, its particular settlements and their main places of interest, the history of their development and their traditional feasts;

- Game quiz "Following the steps of the past of the Mari" which presents the description of folk games, riddles, as well as scripts for the ethnotouristic events.

This electronic educational resource contains a large number of photo and video materials in the "Photo gallery" and "Video" section, which provide visual illustrations for the text information: "The Mari Venice", "The Land of the Mountain Mari", "My Favorite Village-Sernur", etc.

The section "Diagnostic methods" contains tests which help to identify the level of awareness of the children and youth about the ethnic culture of the Mari and the main ethnic places of interest in various districts of the Republic Mari El. 
We haven't limited ourselves to the electronic educational resource alone. In order to upgrade the level of ethnotouristic perception of children we have developed a program of ethnotouristic itineraries around the districts of the Republic Mari El. This program contains the following units:

- Unit 1-description of the itinerary of an ethnic tour for children and youth around the city of Yoshkar-Ola, Medvedevskiy and Orshanskiy districts;

- Unit 2-description of the itinerary of an ethnic tour for children and youth around Paranghinskiy, Mari-Turekskiy, Novo-Toryalskiy, Sernurskiy, Kuzhenerskiy, and Sovetskiy districts;

- Unit 3-description of the itinerary of an ethnic tour for children and youth around Zvenigovskiy, Volzhskiy, and Morkinskiy districts;

- Unit 4-description of the itinerary of an ethnic tour for children and youth around Gornomariyskiy, Kilemarskiy, Yurinskiy districts, and the city of Kozmodemyansk.

Each unit contains information about ethnic places of interest in each district.

\section{Discussion}

According to the program of the itinerary of ethnic tourism we have organized bus tours and walking tours around the sightseeing attractions of the cities and districts of the Republic Mari El. The tours include workshops to demonstrate the fabrication of the national jewelry, clothes, musical instruments, and cooking of the national dishes of the Mari. The tours should result in the children's research projects presented by the participants of the ethnic tour at an academic and research conference.

1) Organization and conduction of tours around the places of interest of the city of Yoshkar-Ola, Medvedevskiy and Orshanskiy districts. Bus tour "Yoshkar-Ola: past and present". Visit to the museum of regional studies in Medvedevo community. Meeting with the relatives of a dramatist N. Arban. "The Mari Christmas"- the atrical performance. The spring of friendship of nations. "The Home land of M. Shketan". Meeting the students of the municipal budgetary general educational institution "Velikopolskaya secondary school of Orshanskiy district". Theatrical performance_-"Pancake Day".

2) Organization and conduction of tours around the places of interest of Paranghinskiy, Mari-Turekskiy, Novo-Toryalskiy, Sernurskiy, Kuzhenerskiy, and Sovetskiy districts. Integration of the cultures of the Mari and the Udmurt people. Traditional costume. National cuisine. Musical instruments. Folk games. The custom of "tying the crow's claw". Mari ritual feasts of Paranghinskiy district. The custom of naming. "The craftsmen of the Olorskaya land". Traditional culture of the Mari people. KirillIvanovichIvanov- the actor in the first sound motion picture"A Start In Life". "Mining"- extraction of natural resources (quarry stone). Planting a tree in a school garden of Sh.Osyp, vil. Marisola, Sernurskiy district. "The Mari Switzerland"-Kuzhenerskiy district. Visiting the Stone Mount. The Pamashyalskiy caves. Sacred groves. Meeting the participants of folk groups of Kuzhenerskiy district. Workshop on fabrication of a bagpipe and wedding decorations of the Mari. Places of interest of Sovetskiy district. Agricultural holding "Akashevskaya". Tribal groves. Chkarinskiy stud farm. Ronghinskiy peat bricks plant.

3) Organization and conduction of tours around the places of interest of Zvenigovskiy, Volzhskiy, and Morkinskiy districts. Research projects for children: "The wonder-lakes-Sea eye, Yalchik". Camping tour. Contest of folk Mari games. Visiting the minor homeland of Z. Prokhorov. Kakshamariy village - the motherland of I. S. Kluchnikov-Palantai. Visiting the sites of the Mari writers and poets of Morkinskiy district: vil. Chavainur, vil. Mizener, etc. Meeting the craftswomen of traditional Mari embroidering.

4) Organization and conduction of tours around the places of interest of in Kozmodemyansk, Gornomariyskiy and Yurinskiy districts. Research projects for children: "The history of the Mountain Mari land"(electronic resource, 2014).Tour to the ethnographic outdoor museum. Workshop on cooking the national dish "kravets". Workshop on willow weaving and home textile wearing. Meeting with the children music group of psaltery players of Gornomariyskiy district. Kilemarskiy district - the land of lakes and rivers. "Freedom"-the recreation of a modern ethnotourist (electronic resource, 2014).Workshop: national cuisine, customs and traditions of the Mari people, traditional songs and dances. A piece of the Zar Russia in the Mari land-Sheremetievskiy castle. The Vetluga river, the Volga. "Men's embroidering"-wood carving. Wooden architecture museums (electronic resource, 2014).

Our work has also implied the conduction of ethno-psychological training for the school children called "Ethnic tourism as a means of tolerance development among the school children", as well the contest "Young researcher", etc. 


\section{Conclusion}

The main intention of our activity is to accelerate the level of ethnic awareness of the children about the culture of the Mari people, and to develop their tolerance and cultural and international interaction.

\section{Acknowledgements}

We express our gratitude to the Russian Humanitarian Scientific Fund for the support of the research project.

\section{References}

Fedorova, C. (2014). Development of Ethnotourism for Children and Youth in the Republic Mari El: Theoretical Bases and Diagnostics Results. Yoshkar-Ola: Mari Institute of Education.

Fedorova, C. (2014). Scientific Methodological and Psycho-pedagogical Follow-up for the Development of Ethnotourism for Children and Youth in the Republic Mari El. Yoshkar-Ola: Mari Institute of Education.

Huhlaeva, O. (2013). Multicultural education. Moscow: Publishing Yurayt.

Ivleva, M. (2014). Ecological Aspect of the Analysis of a Project for Economic Development of the Kurshskaya Kosa (Curonian Spit) National Park as a Specially Protected Natural Territory.

Kilemarsky, D. (2014). http://www.12rus.ru/list/24/955/

Mari culture will be presented at the ethnographic festival. (2013). "Land of Ancestors" at Arda settlement. Retrieved from http://finugor.ru/node/41653

Yurinsky, D. (2014). https://ru.wikipedia.org/wiki

\section{Copyrights}

Copyright for this article is retained by the author(s), with first publication rights granted to the journal.

This is an open-access article distributed under the terms and conditions of the Creative Commons Attribution license (http://creativecommons.org/licenses/by/3.0/). 